\title{
Economic Sanctions against Russia: Assessing the Policies to Overcome their Impact ${ }^{1}$
}

Starting from 2014 the European Union countries, the United States of America and some other states imposed economic sanctions against Russia, resulting in diversification of trade ties away from western partners ("pivot to the East" strategy). The mixed findings of recent sanctions literature related to their effectiveness and measures to overcome the negative consequences, has necessitated the examination of these issues for the case of anti-Russian economic sanctions. We use various macroeconomic data along with indicators of digital development and financial inclusion. The methodology comprises a combination of graphical, comparative, and correlation analysis. The analysis of external sector data shows that economic sanctions had substantial negative impact on trade and foreign direct investment with main senders. At the same time, the "pivot to the East" after 2014 has not been implemented yet as much as expected. To overcome negative impact of sanctions and to promote economic growth, the current diversification of ties should be accompanied by other measures, centred on digital development, digital financial technologies, and financial inclusion. We assess linkages between digital development and wealth inequality and we found that in most countries with moderate wealth inequality, including Russia, the digital transformation could bring more benefits in terms of economic growth, than in countries with lower wealth inequality. The overall study allowed us to examine digital policy implications to overcome the negative effects of sanctions in Russia. The obtained results will contribute to addressing the problem of optimisation of Russia's behaviour as a target country that is the subject of future research.

Keywords: economic sanctions, Russia, "pivot to the East", commodity trade, foreign direct investment, economic growth, digital transformation, financial inclusion, wealth inequality, comparative analysis

\section{Acknowledgments}

The article has been prepared with the support of the Russian Foundation for Basic Research and the Chinese Academy of Social Sciences, the research project No. 19-51-93009 "The trade policy of Russia and China in the context of the transformation of the international trading system".

For citation: Belozyorov, S. A. \& Sokolovska, O. (2020). Economic Sanctions against Russia: Assessing the Policies to Overcome their Impact. Ekonomika regiona [Economy of region], 16(4), 1115-1131, https://doi.org/10.17059/ekon. reg.2020-4-8

\footnotetext{
${ }^{1}$ (c) Belozyorov S. A., Sokolovska O.
} 
а, б) Санкт-Петербургский государственный университет, Санкт-Петербург, Российская Федерация a) https://orcid.org/0000-0001-8711-2192,e-mail: s.belozerov@spbu.ru 6) https://orcid.org/0000-0002-4259-3786

\title{
Экономические санкции против России и оценка политики по преодолению их последствий
}

\begin{abstract}
В 2014 году страны Европейского союза, Соединенные Штаты Америки и некоторые другие государства ввели экономические санкции против России, что привело к диверсификаиии торговых связей и изменению отнотений с западными партнерами (стратегия «поворота на Восток»). Неоднозначные выводы современных исследований, посвященных эффективности санкций и мер по преодолению их негативных последствий, обосновали необходимость рассмотрения данных вопросов на примере антироссийских экономических санкиий. Проанализированы различные макроэкономические данные, а также показатели иифрового развития и финансовой доступности. Данное исследование основывается на методах грабического, сравнительного и корреляционного анализа. Анализ данных внешнего сектора показывает, что экономические санкиии негативно повлияли на торговлю со странами-инициаторами и прямые иностранные инвестиции. В то же время, «поворот на Восток» до сих пор не реализован в полном объеме. Для преодоления негативного влияния санкиий и усиления экономического роста диверсификация связей должна сопровождаться другими мерами, сосредоточенными на иифровом развитии, иифровых финансовых технологиях и доступности финансовых услуг. Анализ взаимосвязи между иифровым развитием и неравенством в доходах выявил, что, с точки зрения экономического роста иифровая трансформация может принести больше пользы странам с умеренным неравенством, включая Россию, нежели странам, где неравенство выражено в меньшей степени. Изучено, каким образом иифровая политика может повлиять на преодоление негативных последствий санкиий в России. Полученные результаты помогут решить проблему оптимизации поведения России как странь, ставщей объектом санкиий, что является предметом дальнейших исследований.

Ключевые слова: экономические санкции, Россия, поворот на Восток, торговля товарами, прямые иностранные инвестиции, экономический рост, цифровая трансформация, финансовая доступность, имущественное неравенство, сравнительный анализ
\end{abstract}

\section{Благодарность}

Исследование выполнено при поддержке гранта РФФИ и Академии общественных наук Китая, проект № 19-5193009 «Торговая политика России и Китая в условиях трансформации международной торговой системы».

Для цитирования: Белозеров С. А., Соколовская Е. Экономические санкции против России и оценка политики по преодолению их воздействия // Экономика региона. 2020. Т. 16, вып. 4. С. 1115-1131. https://doi.org/10.17059/ekon. reg.2020-4-8

\section{Introduction}

In 2014, the European Union (EU) countries, the United States of America (the U.S.) and some other states have imposed economic sanctions against Russia, providing both financial and trade restrictions. The vulnerability of the national economy to economic sanctions caused the diversification of trade ties, the so-called "Russia's pivot to the East", as the country shifted from western partners. Now, Russia is looking for new markets and investment opportunities in eastern countries, particularly in China, to replace what has come under the ban of western economic sanctions.

However, have the pivot to the East accomplished as much as expected to help Russia overcome the negative effects of economic sanctions on trade and investment and restore economic growth? Should the government pay more attention to other policies relying principally on domestic resources?

To answer these questions, the paper aims to:
1) determine the incidence of economic sanctions against the external sector based on the analysis of trade and investment flows between both Russia and sanctions proponents (the EU countries and the U.S.), and Russia and China;

2) identify policies to overcome the negative effects of western economic sanctions based on the examination of the impact of digital transformation on economic development.

The analysis of recent development trends and factors, contributing to economic growth in both advanced and developing economies, allowed identifying digital transformation as one of the key drivers of economic and social development. However, the under-researched impact of digital development on macroeconomic performance leads to significant challenges in this field. An important macroeconomic indicator affecting both economic growth and financial inclusion is the income or wealth inequality. This study aims to contribute to the existing litera- 
ture by assessing linkages between digital development and wealth inequality to identify whether digital measures can be a valuable tool for Russia to overcome negative consequences of economic sanctions, if these measures do not worsen wealth inequality.

The paper is structured as follows. Section II provides literature review of theoretical and empirical studies related to economic sanctions and summarises the background of relevant western anti-Russian economic sanctions. Section III briefly describes data and methodology. Section IV estimates the impact of economic sanctions on selected indicators of Russian economic performance and provides cross-country comparisons of digital transformation and economic development. Section $\mathrm{V}$ addresses policy implications and contains concluding remarks.

\section{Literature Review and Theoretical Background}

A number of theoretical economists and experts of international financial and economic organisations investigated economic sanctions and their ability to resolve international conflicts.

The issues of compliance of economic sanctions with international law were considered as early as in the beginning of the 20th century. As international merchandise trade played an important role, the sanctions literature of the time mainly focussed on customs boycott (see for example, M.A. Maday [1], H. Lauterpacht [2]).

The increase in globalisation along with gradual elimination of customs duties and growing trade in intangibles led to the extension of the current research on political and institutional effects. The accumulated experience in applying sanctions enabled quantitative comparisons. For example, F. Hoffmann [3] analysed two case studies: the decision made by the League of Nations to apply sanctions against Italy in 1935, and the decision of the British Government to apply sanctions against Rhodesia in 1965.

In both cases, the sanctions were motivated by political reasons, and the author concludes that in such a case the probability of successful sanctions is low.

R. MacDonal [4] investigated the enforcement of international public policy by international political organisations, especially through economic modalities. The research was extended by M. Doxey [5], who developed another case study related to the role of sanctions imposed by the United Nations on Rhodesia in 1965 and South Africa in the 1960s, focussing on the status of the United Nations as a sanctioning body, and by
J. Barber [6], who analysed the economic sanctions both as an independent tool to replace the use of force and as the supplementary measure.

J. Eaton \& M. Engers [7] developed notions of sender country and target country that depend on the country's patience and the extent of their suffering from sanctions. The authors concluded that less harmful sanctions imposed on the target can sometimes be more effective than those that impose greater harm.

The «Economic Sanctions Reconsidered» (first published by G. Hufbauer et al. in 1985) is the first well-known comprehensive study of economic sanctions, investigating their history, causes and rationales. In the study, the authors also aimed to assess the effectiveness of economic sanctions using the cost-benefit analysis [8].

Such an approach was criticised by R. Pape [9; 10], who revealed that sanctions have succeeded in only 5 of 115 (according to G. Hufbauer et al.) successful attempts. In addition, he concluded that economic sanctions are ineffective to achieve economic goals.

Generally, the development of new research methodologies and tools, such as conflict theory, institutional theory and economic and mathematical modelling enabled more sound evaluation of the impacts of sanctions on both national economy and selected regions and economy sectors.

In particular, the impact of economic sanctions for various scenarios (different political regimes, military conflicts etc.) was assessed in works of G. Tsebelis [11], J. Dashti-Gibson et al. [12], H. Askari et al. [13], G. Hufbauer et al. [14], H.-M. Kim [15], A. Escribà-Folch [16],

The results of theoretical and empirical studies were translated into the United Nations recommendations for designing the targeted economic sanctions [17]. The main conclusion is that targeted economic sanctions should always be combined with other measures and never applied in isolation. Moreover, they must be assessed and integrated within an overall approach to international peace and security challenges.

The implementation of anti-Russian economic sanctions led to a number of investigations aiming to assess their impact on real and financial sectors of the Russian economy from the European Union (EU) and World Trade Organization (WTO) experts as well as Russian scientists.

The EU issued several documents to assess the impact of economic sanctions on Russia. The EU experts noted, inter alia, that quantitative estimates of the impact are difficult to examine. However, most observers agree that 
sanctions are slowing the country's economic growth ${ }^{1}[18,19]$.

The WTO experts argue that the Russian economy is particularly vulnerable to EU and U.S. economic sections due to a limited diversification of its economy and a high dependency on raw materials [20].

M. Klinova \& E. Sidorova [21] examined the mutual influence of economic sanctions of the EU and Russia in the framework of economic relations. They concluded that the implementation of sanctions generates autarchy and influences economic development prospects. The regional aspect of the "pivot to the East" caused by economic sanctions, namely, the sustainable development of the Russian Far East in new economic development strategy, is discussed by P. Minakir [22].

The comprehensive study "Economic Sanctions against Russia: Expectations and Reality" [23] analysed reasons and content of anti-Russian economic sanctions, using macroeconomic analysis, economic forecasting and scenario approach. Additionally, the authors analysed the Bank of Russia's economic policy and its impact on the main macroeconomic indicators, determined benefits and challenges of import substitution and export-oriented economy, and the reasonability of the "pivot to the East".

The general conclusion is that sanctions, worsening the business climate in Russia, are not the main source of current economic problems; the reason is the failure of the overall economic pattern.

In the second part of this section, we summarise the background of relevant western anti-Russian economic sanctions by comparing sanctions, imposed by the EU countries and the U.S.

U.S. sanctions on Russia fall into several broad categories:

- blocking sanctions against individuals and entities,

- presumption of denial to designated end users for export licences,

- economic sanctions, namely, sectoral sanctions against entities operating in sectors of the Russian economy (they apply to specific entities in Russia's financial, energy, and defence sectors and prohibit U.S. individuals and entities from engaging in transactions related to lending, investment, and/or trade with entities on the "sanction list", but they permit other transactions),

\footnotetext{
1 Geopolitical Outlook for Europe. Confrontation vs Cooperation. (2018). European Political Strategy Center (EPSC). Retrieved from: https://ec.europa.eu/epsc/sites/epsc/ files/epsc_brief_geopolitical.pdf (Date of access: 30.07.2019).
}

- investment ban and prohibition on the exportation or importation of goods, technology, or services to or from the Crimea region ${ }^{2}$.

The EU adopted anti-Russian economic sanctions in July/September 2014 (two weeks after the U.S. announced economic sanctions on 16 July 2014) and have been renewing them every six months. The latest renewal was on 27 June 2019; the economic sanctions targeting specific sectors of the Russian economy were extended until 31 January $2020^{3}$.

EU's Ukraine-related sanctions progressed from diplomatic sanctions (Tier 1), to individuals/entities sanctions (Tier 2), and, finally, to economic sanctions (Tier 3).

Table 1 demonstrates the comparison of EU and U.S. anti-Russian economic sanctions in regards to different aspects of their use.

U.S. and EU economic sanctions on Russia have been complemented by similar sanctions imposed by Australia, Canada, Japan, and Iceland. Norway, Switzerland, Ukraine, and the EU candidate countries Albania and Montenegro formally align the anti-Russian sanctions with those imposed by the EU. However, economic sanctions, imposed by the U.S. and EU countries, have a major impact on epy external sector.

\section{Data and Methodology}

In this study, we use various macroeconomic data along with indicators of digital development and financial inclusion.

A) External sector statistics for 2012-2018, provided by the World Band and Central Bank of Russia (CBR):

- commodity trade (exports and imports),

- inward and outward foreign direct investment (FDI) flows.

B) Macroeconomic indicators for 2012-2018, provided by the World Band, International Labor Organization (ILO), Credit Suisse Research Institute and Federal State Statistics Service (Rosstat):

- gross domestic product (GDP) per capita in local currency units (LCU),

- annual GDP growth based on constant local currency,

2 Ukraine-Russia-related Sanctions Program. (2016). Office of Foreign Assets Control. U.S. Department of the Treasury. Retrieved from: https://www.treasury.gov/resource-center/ sanctions/Programs/Pages/ukraine.aspx (Date of access: 30.07.2019)

${ }^{3}$ Council of the European Union. (2019). Russia: EU prolongs economic sanctions by six months. Retrieved from: https:// www.europeansources.info/record/russia-eu-prolongs-economic-sanctions-by-six-months-4/ (Date of access: 30.07.2019) 
咅

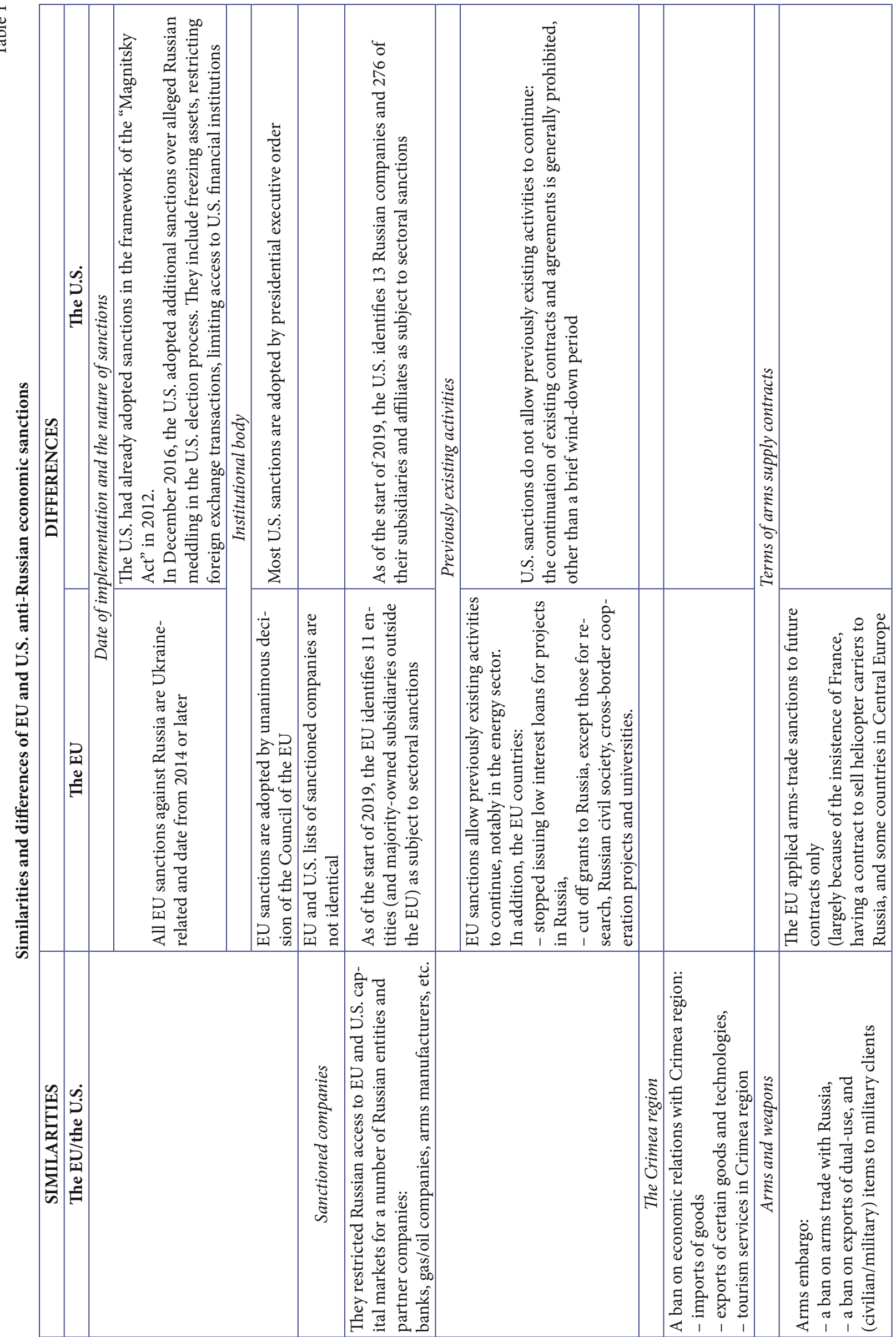




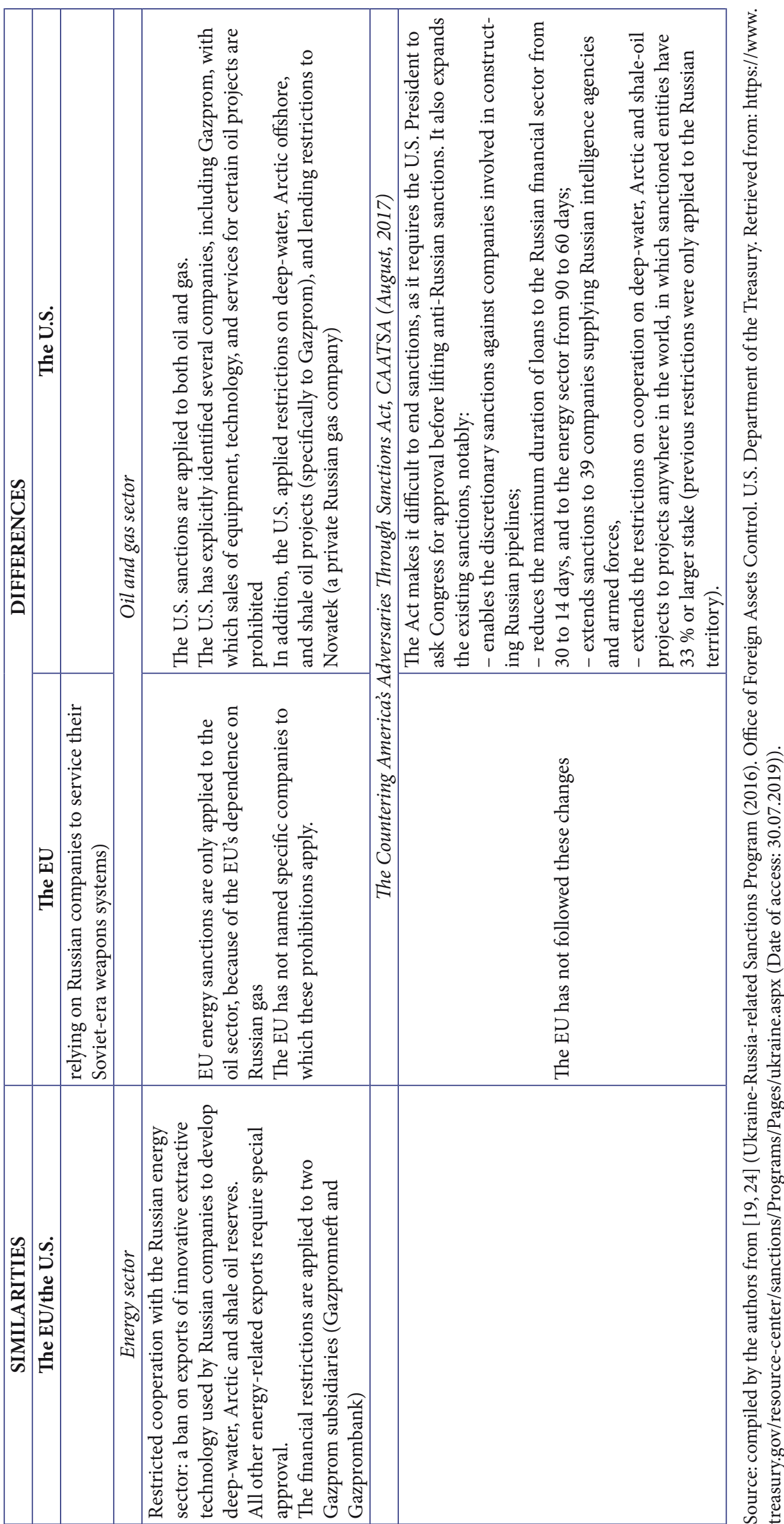


- population with money income below the subsistence minimum level (P_MIBSML), determined on the basis of the data on the distribution of population according to the level of average per capita money income compared to the subsistence minimum level,

- unemployment, which refers to the share of the labour force that is without work but available for and seeking employment, and

- income Gini index, referring to the index of income inequality.

- wealth Gini index, measuring the extent to which the distribution of wealth among individuals or households within an economy deviates from a perfectly equal distribution. A Gini index of 0 refers to perfect equality, while an index of 100 implies perfect inequality.

C) Indicators of digital development and financial inclusion for 2017, provided by IMD World Competitiveness Center (Switzerland) and the World Bank:

- digital competitiveness, calculated based on 51 ranked criteria grouped into three digital competitiveness factors:

- knowledge: the intangible infrastructure, underlining the process of digital transformation;

- technology: the overall context that enables the development of digital technologies,

- future readiness: the preparedness of an economy to assume its digital transformation ${ }^{1}$.

- made or received digital payments, which refers to the percentage of adult respondents (age $15+)$ who reported using mobile money, a debit or credit card, or a mobile phone to make a payment from an account, or reported using the internet to pay bills or to buy something online (in the past 12 months). It also includes respondents who reported paying bills, sending or receiving remittances, receiving payments for agricultural products, receiving government transfers, receiving wages, or receiving a public sector pension directly from or into a financial institution account or through a mobile money account in the past 12 months

\footnotetext{
${ }^{1}$ In turn, each of these factors is divided into 3 sub-factors, highlighting every facet of the areas analysed. These 9 sub-factors comprise 51 criteria. Each sub-factor, independently of the number of criteria it contains, has the same weight in the overall consolidation of results, that is approximately $11.1 \%(100 / 9$ 11.1). Criteria can be hard data, which analyse digital competitiveness as it can be measured (e.g. Internet bandwidth speed) or soft data, which analyse competitiveness as it can be perceived (e.g. Agility of companies). Hard criteria represent a weight of $2 / 3$ in the overall ranking, whereas the survey data represent a weight of $1 / 3$. Finally, aggregating the results of the 9 sub-factors makes the total consolidation, which leads to the overall ranking of the World Digital Competitiveness.
}

The methodology comprises a combination of graphical, comparative, and correlation analysis.

\section{Results and Discussion}

\section{A. Impact of economic sanctions on external sector}

In the first part of this section, we analyse the trade and investment flows between Russia and main sender countries (the U.S. and the EU countries) before and after 2014. In addition, we compare the data with those of China, which is a major Russian trading partner in the East.

Figure 1 presents the dynamics of commodity exports in 2012-2019 (the latest available data).

The gradual decline in commodity exports started in 2013 and reached its minimum values in 2016. In 2017-2018, Russian exports to all analysed trading partners grew by different rates: the highest rate was for China (almost twofold increase), while the rates for both the EU and the U.S. were approximately 1.3 times higher than in 2016. However, in 2019, the value of this indicator declined for both the EU and China, while for the U.S. it is possible to observe a slight increase.

The share of Russia as an EU export trading partner has gradually declined from $7.3 \%$ in 2012 to 4.1 in 2015-2016. Now it stands at $3.9 \%$.

Figure 2 demonstrates the dynamics of commodity imports in 2012-2019 (the latest available data).

It can be observed that import trends are similar to export trends: the minimum values in 2015-2016 for all analysed trading partners and the sharp decline in Russian imports from the EU countries in 2013-2016.

In 2017, there was a decrease in imports from all analysed trading partners. While in 2019 this indicator slightly increased for both China and the U.S., it continued to decline for the EU. The share of Russia as an EU import trading partner has increased from $7.0 \%$ in 2016 to $7.5 \%$ in 2019 . The highest share was in 2013 (amounted to $12.3 \%$ ).

Simultaneously, the structure of commodity exports and imports has not changed significantly in 2012-2019.

In the second part of this section, we analyse another important economic indicator reflecting the state of international economic relations, namely, inward and outward foreign direct investment (FDI)

Figures 3 and 4 demonstrate Russian net FDI inflows and outflows in 2012-2019 by partner countries (EU countries, the U.S., and China).

Figures 3 and 4 clearly demonstrate the negative impact of EU and U.S. economic sanctions on both Russian inward and outward FDI. 


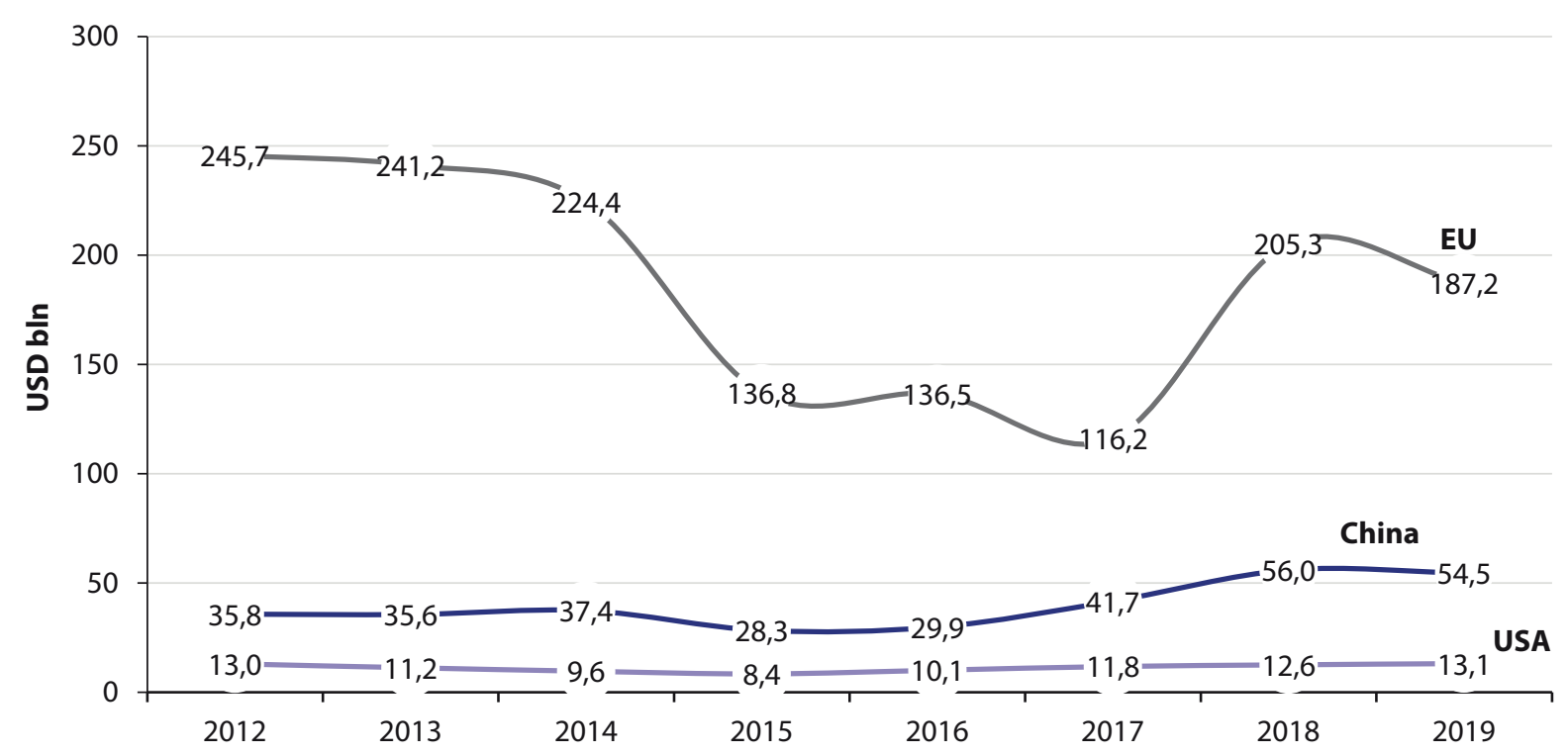

Fig. 1. Commodity exports from Russia to the EU countries, the U.S., and China, 2012-2019 Note: hereinafter: mainland China

Source: compiled by the authors, based on the United Nations Conference on Trade and Development (UNCTAD) data (UNCTAD. Retrieved from: https://unctadstat.unctad.org/(Date of access: 22.10.2020))

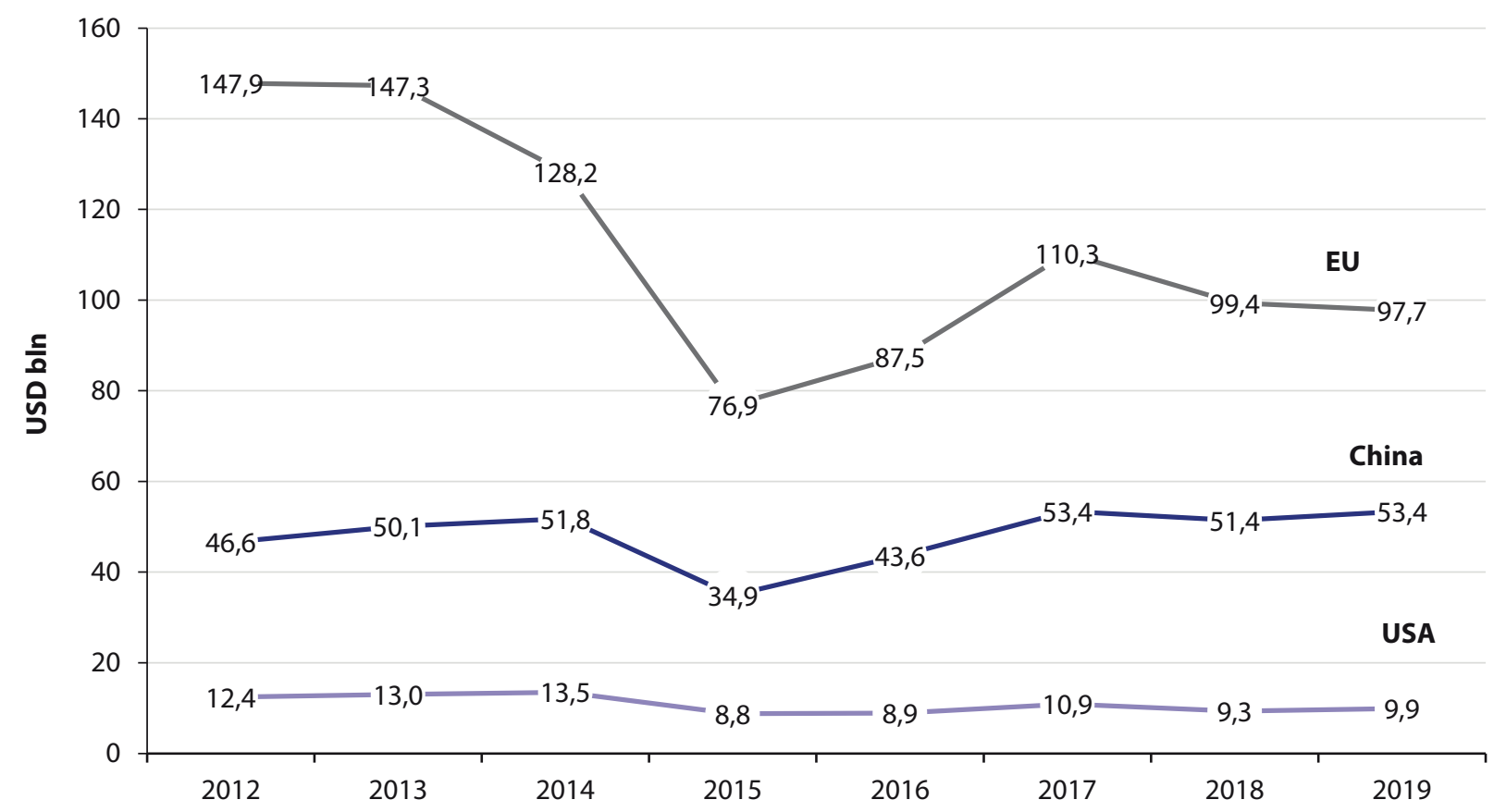

Fig. 2. Commodity imports from the EU countries, the U.S., and China to Russia, 2012-2019

Source: compiled by the authors based on UNCTAD data (UNCTAD. Retrieved from: https://unctadstat.unctad.org/ (Date of access: 22.10.2020))

The sharp decrease in EU investments in Russia in 2018 is due to the decrease in investment from Cyprus (net inflow was -10312.9 mln USD caused by the tightening of banking laws and enforcement of tax information exchange (TIEA)), who was the main investor in Russia among the EU countries.

The gradual decline in the net inflow of Chinese investments in Russia that started in 2014 (1272.03 mln USD in 2014 to -12.8 mln USD in 2018 ) is determined mainly by the poor invest- ment climate. However, Russian outward FDI to China shows substantial growth in 2017 (from 5.9 mln USD in 2016 to $43 \mathrm{mln}$ USD in 2019).

The variation of net inflow and outflow of Russian FDI from and to the U.S. is marginal. However, it is possible to observe the negative impact of economic sanctions: $738.5 \mathrm{mln}$ USD in 2014 compared to $-105 \mathrm{mln}$ USD in 2019 of inward FDI; $1653.5 \mathrm{mln}$ USD in 2014 compared to $-4 \mathrm{mln}$ USD in 2019 of outward FDI. 


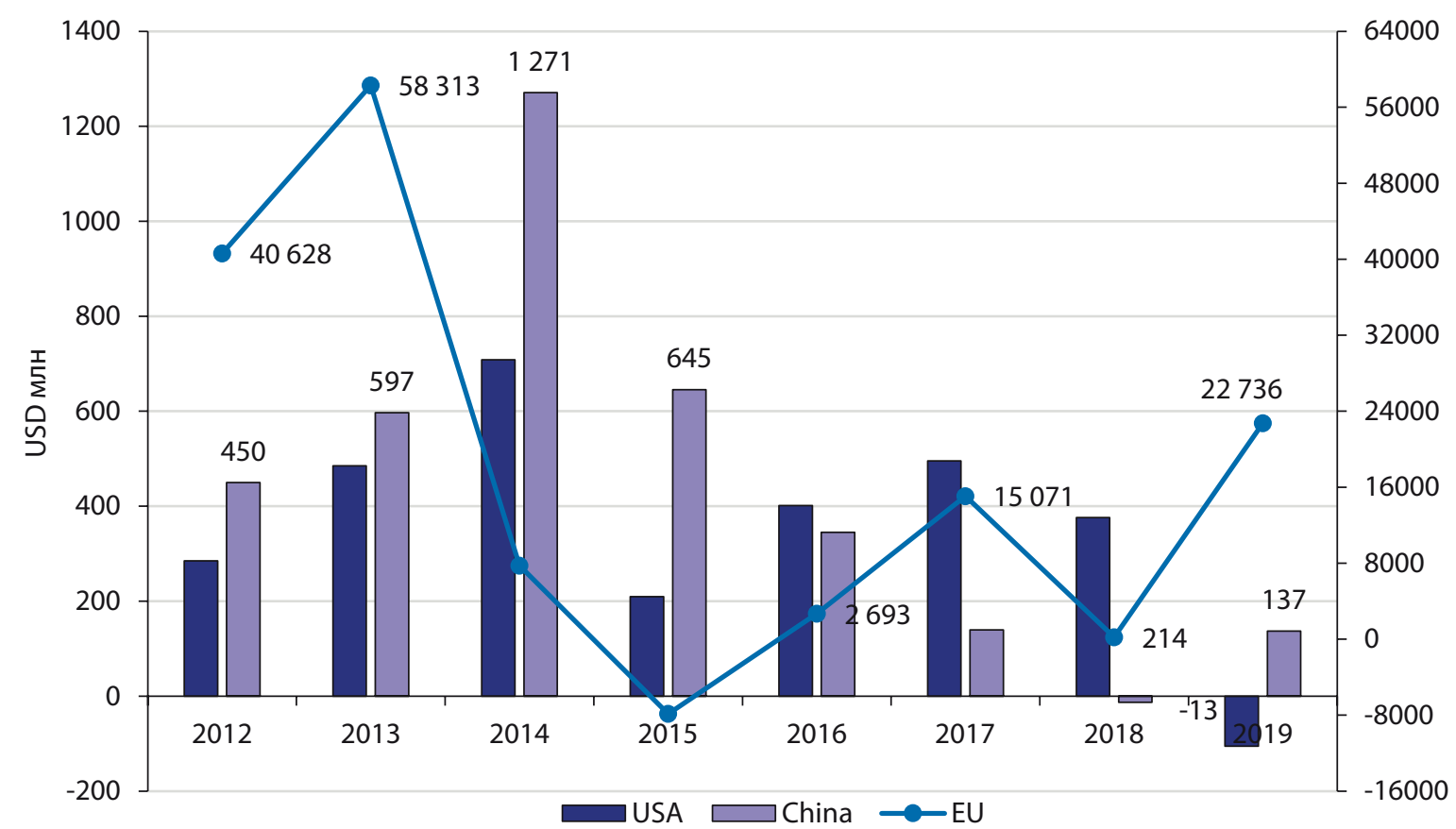

Fig. 3. Russian net FDI inflows from the EU countries, the U.S., and China, 2012-2019

Notes: a) hereinafter FDI refers to the sum of equity capital, reinvestment of earnings, and other capital; $b$ ) a positive sign denotes a net increase; a negative sign denotes a net decrease.

Source: compiled by the authors based on CBR data (CBR External Sector Statistics. Retrieved from: https://www.cbr.ru/eng/statistics/macro_itm/svs/(Date of access: 22.10.2020))

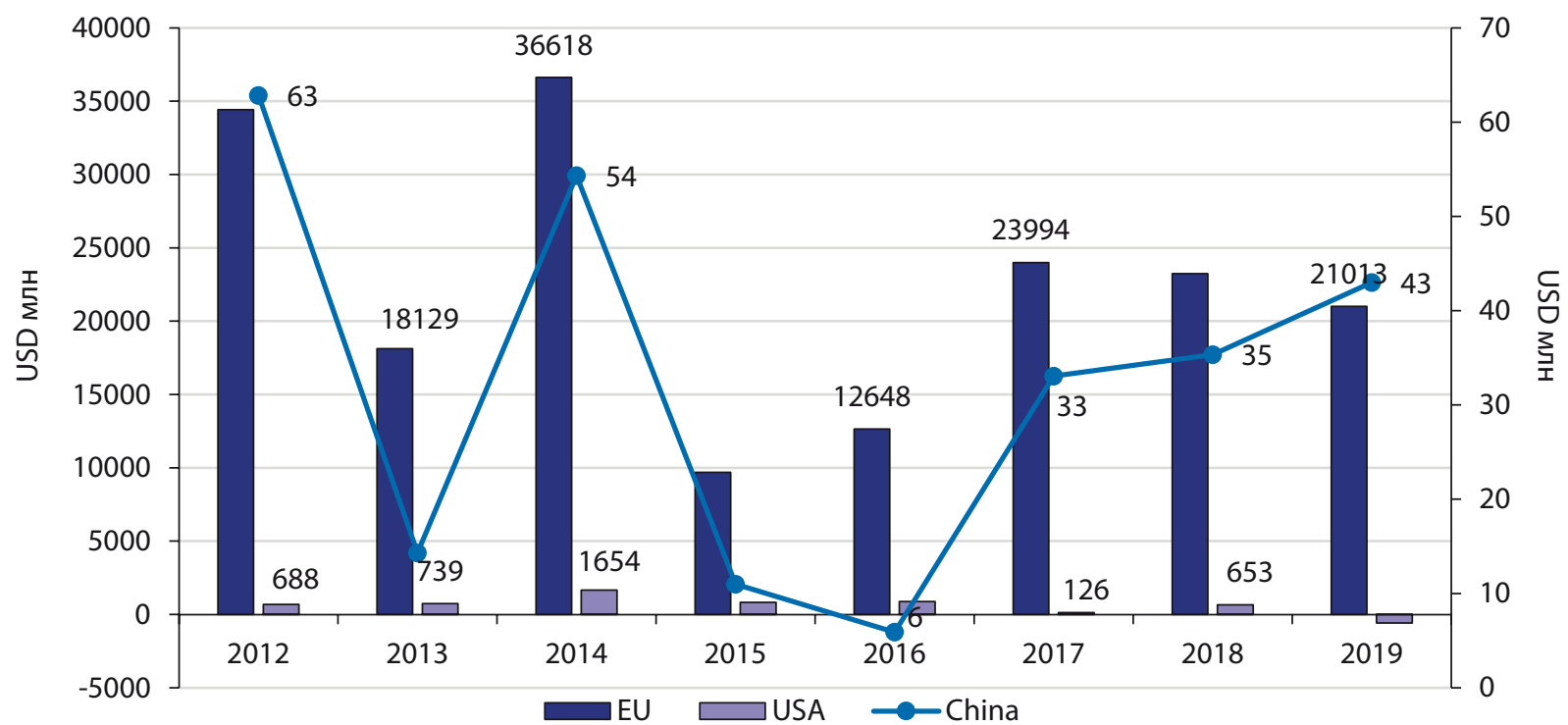

Fig. 4. Russian net FDI outflows to the EU countries, the U.S., and China, 2012-2019

Source: compiled by the authors based on CBR data (CBR External Sector Statistics. Retrieved from: $h$ ttps://www.cbr.ru/eng/statistics/macro_itm/svs/(Date of access: 22.10.2020))

B. Impact of economic sanctions on macroeconomic indicators

The negative impact of economic sanctions on key Russian social and economic indicators can be clearly seen (Figures 5 and 6).

To summarise, we can suggest that EU and U.S. economic sanctions against Russia had a substantial negative effect on Russian exports and imports to the EU and a marginal negative effect on
Russian exports and imports to the U.S. Apart from that, the structure of commodity exports and imports has not changed significantly in 2012-2019; the changes refer only to trade volumes.

We found FDI to be more sensitive to anti-Russian EU and U.S. economic sanctions than trade in goods. However, when it comes to Russian FDI to and from the EU countries, it should be considered that some of these states (Ireland, Switzerland, 


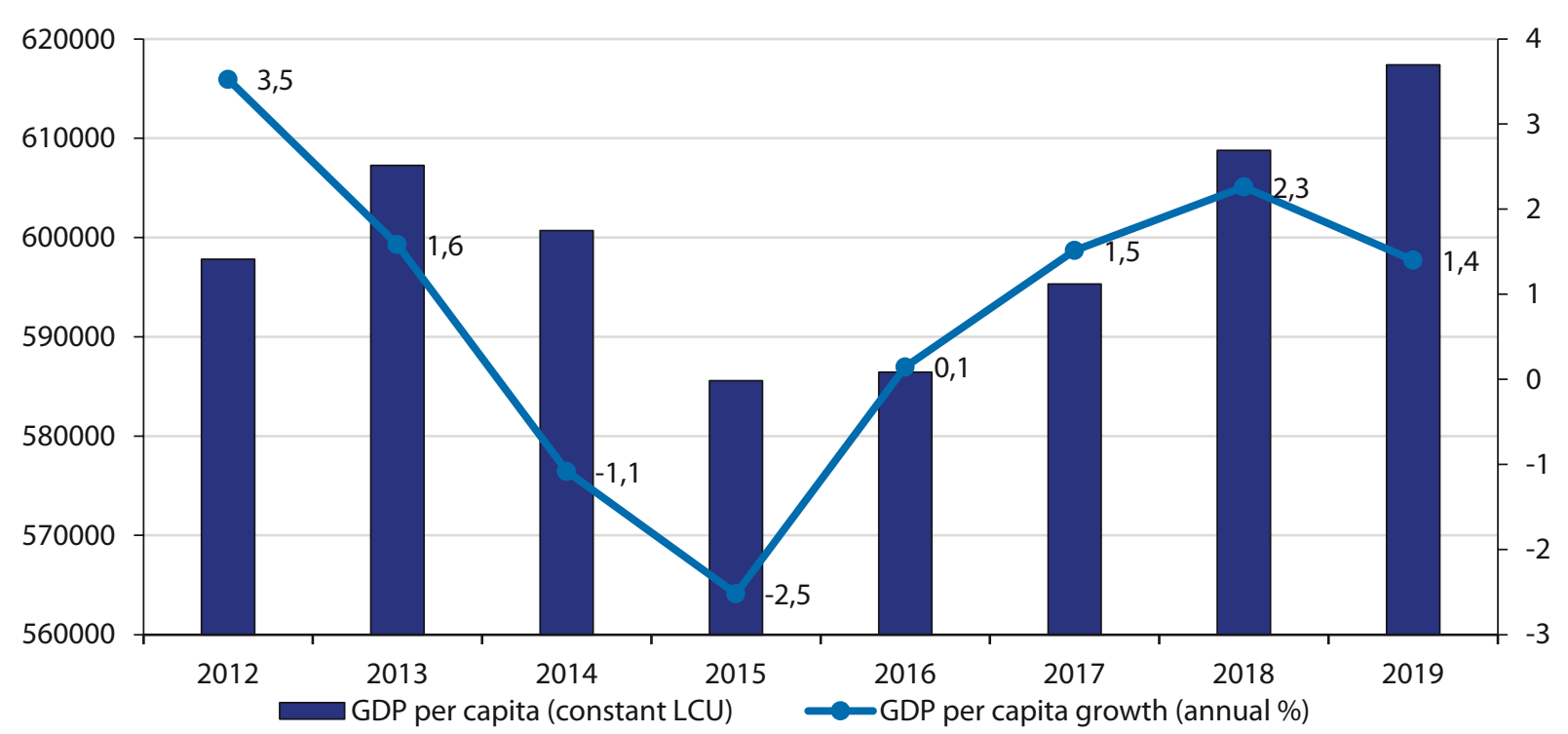

Fig. 5. GDP per capita and GDP per capita growth rates in Russia, 2012-2019

Source: compiled by the authors based on the World Bank data (The World Bank database. Retrieved from: https://data.worldbank.org/(Date of access: 22.10.2020))

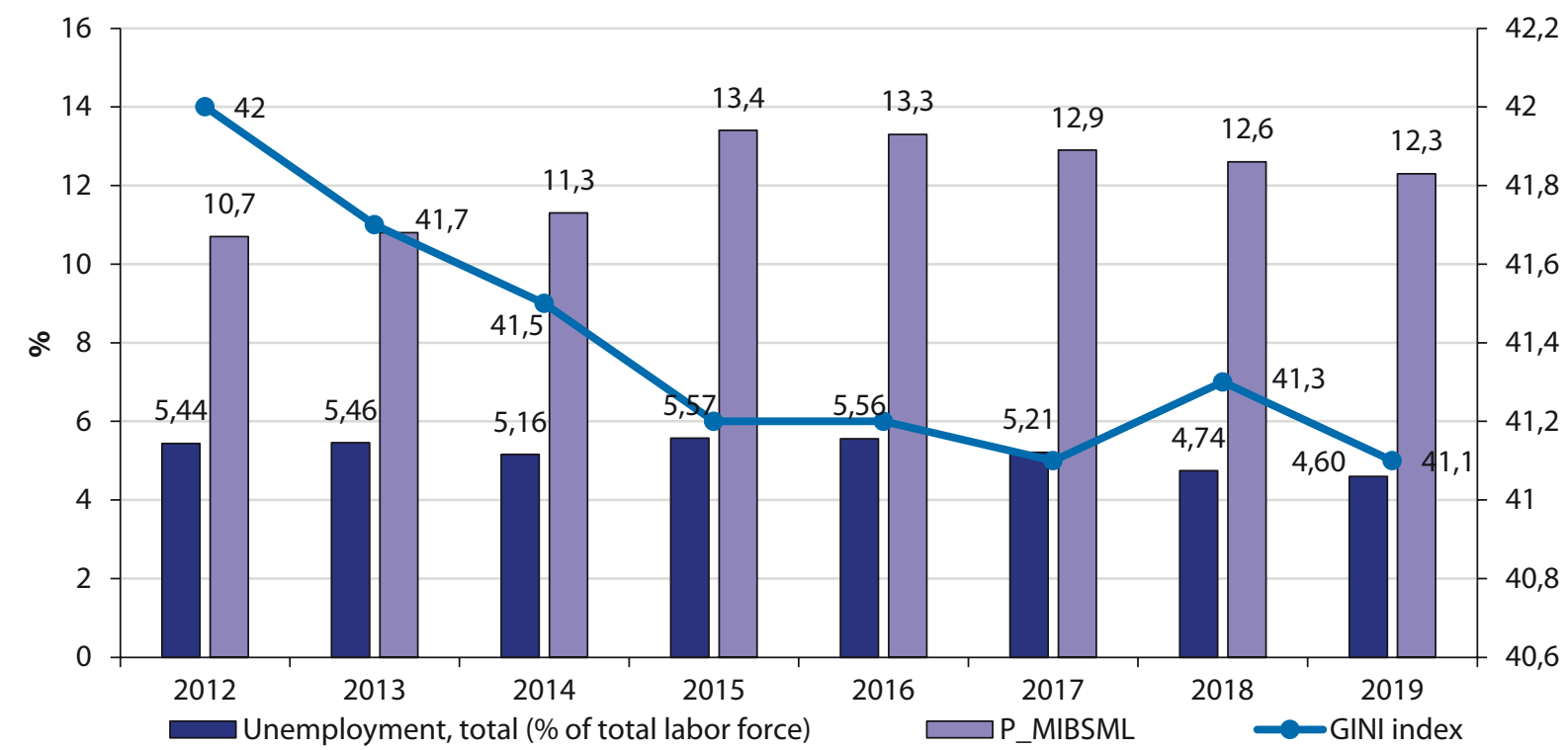

Fig. 6. Indicators of social development in Russia, 2012-2019

Source: compiled by the authors based on the Rosstat data (Russian Federation Federal State Statistics Service (Rosstat). Retrieved

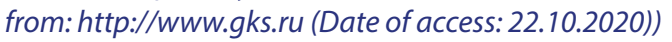

Note: $P \_$MIBSML refers to population with money income below the subsistence minimum level

Malta, British and Dutch overseas territories) are "authorised" offshore zones for Russian business. This fact implies the rapid changes in tax legislation concerning new rules of tax harmonisation and anti-money laundering, aimed to prevent tax optimisation. That, in turn, has an impact on FDI flows independent of economic sanctions.

Considering the "pivot to the East", after 2014, as illustrated by China's example, it is possible to observe that both Russian exports and imports have been gradually increasing, as contrasted with FDI. The net inward investment from China to Russia has decreased over 2014-2018.
The Chinese investors are not entirely motivated by political reasons, considering principally the risk-return ratio. The increase in net inflow in 2019 was due to Chinese investment projects implemented in the Russian Far East. However, 2020 Q1 shows that the net inward investments from China to Russia became negative ( -70 bln USD).

Therefore, it is fair to assume that the "pivot to the East" aimed to overcome the negative impact of economic sanctions should be accompanied by other measures. In the contemporary context, it is reasonable to link such policies with digital transformation. 


\section{Financial inclusion and digital financial development}

A growing body of research reveals that currently a powerful tool to promote economic growth and social development is the people's financial inclusion.

One of the main instruments broadly recognised by policy makers and regulators as important in reducing poverty and achieving economic growth is financial inclusion. The term means the wide access to and use of formal financial services (mainly bank accounts and digital payments). In many countries worldwide, the expansion of financial inclusion is a priority in financial sector development. Financial inclusion potentially benefits both senders and receivers in terms of improved efficiency of payments [27].

The delivery of traditional and new financial services based on broad types of users and combined with IT establishes the FinTech environment.

According to R. Pepper \& J. Garrity [25] and M. Graham [26], the World Bank's studies suggest a decrease in global income inequality because of financial inclusion. However, the adoption of information and communication technologies contributes to the increase in income inequality observed in individual countries.

Financial inclusion can help reduce poverty and income/wealth inequality by improving people's income earning potential through using mobile money services and lowering the cost of receiving payments. Those aspects are of great importance for Russia, where the low purchasing power of the population is one of the main barriers for the development of Russia's FinTech market. According to Rosstat, the share of the population with money income below the subsistence minimum level in Russia increased from $11.2 \%$ in 2014 to $13.3 \%$ in 2015-2017; now it stands at $12.9 \%$.

In addition, financial inclusion enables people to effectively manage individual financial risk, promotes the accumulation of savings and helps reduce corruption and informal economy due to switching from cash to digital payments [27].

The level of people's financial inclusion is directly related to the development of digital financial technologies in the country. According to E\&Y estimates, in 2017, the share of the population regularly using FinTech (the FinTech Adoption Index) in Russia was $35 \%$, while the world average was $33 \%$. In 2019, Russia this value amounted to $82 \%$ (the 3rd place after China and India) with the world average of $64 \%$.

The regular FinTech user is someone, who has used two or more financial technologies over the last 6 months [28, 29].
However, it should be noted that the Russian FinTech Adoption Index was calculated using mainly the data collected in Moscow and Saint Petersburg only. In this respect, in 2017, the cities left behind were New York (33.1\%), Hong Kong (29.1\%) and London (25.1\%). The study also revealed the correlation between FinTech use and income factor ${ }^{1}[30]$.

The concentration of FinTech users in major cities is one of the main features of the Russian FinTech market. Another specific feature (compared to the EU and the U.S.) is the lack of regulation in some sectors of FinTech. For example, currently, the law does not regulate collective investments, cryptocurrencies and peer-to-peer (P2P) lending.

In addition, Russia is considered a key supplier of IT-specialists for the FinTech world market. This fact has a mixed impact on the FinTech growth in the country: Russian professionals often migrate since it is more profitable for them to work abroad ${ }^{2}$.

However, the number of individual's digital financial operations does not fully reflect the country's digital competitiveness, i.e., the extent to which a country adopts and explores digital technologies. This refers, in turn, to the transformation in government practices, business models and society in general [31].

According to the IMD World Digital Competitiveness Ranking 2018, Russia placed 40th among 63 economies [32].

Moreover, according to the Reed Smith company survey of 100 corporate senior executives (CEO, CIO, Director of Strategy) in the financial services sector, Russia is not among the most attractive countries for FinTech investors: only $1 \%$ of respondents are ready to make their next FinTech acquisition and/or investment in Russian FinTech companies ${ }^{3}$.

\footnotetext{
${ }^{1}$ FinTech Adoption Index — Russia: Key Trends. (2016). Ernst \& Young Valuation and Advisory Services LLC. Retrieved from: https://www.ey.com/ru/en/newsroom/news-releases/newsey-fintech-adoption-index-in-moscow-and-st-petersburg-exceeded-that-in-worlds-other-largest-cities (Date of access: 30.07.2020).

2 Private FinTech as a tool for sustainable business development in Russia and Kazakhstan. FinTech market trends. (2018). Deloitte CIS Research Center. Retrieved from: https:// www2.deloitte.com/content/dam/Deloitte/ru/Documents/research-center/FinTech-Market-Trends\%202018-en.pdf (Date of access: 30.07.2020).

${ }^{3}$ Tech control: How FinTech M\&A is shaping the financial future. (2018). Reed Smith LLP. Retrieved from: https://www. paymentscardsandmobile.com/wp-content/uploads/2018/11/ Fintech-2018-MA-Report_FINAL_LR.pdf (Date of access: 30.07.2020).
} 


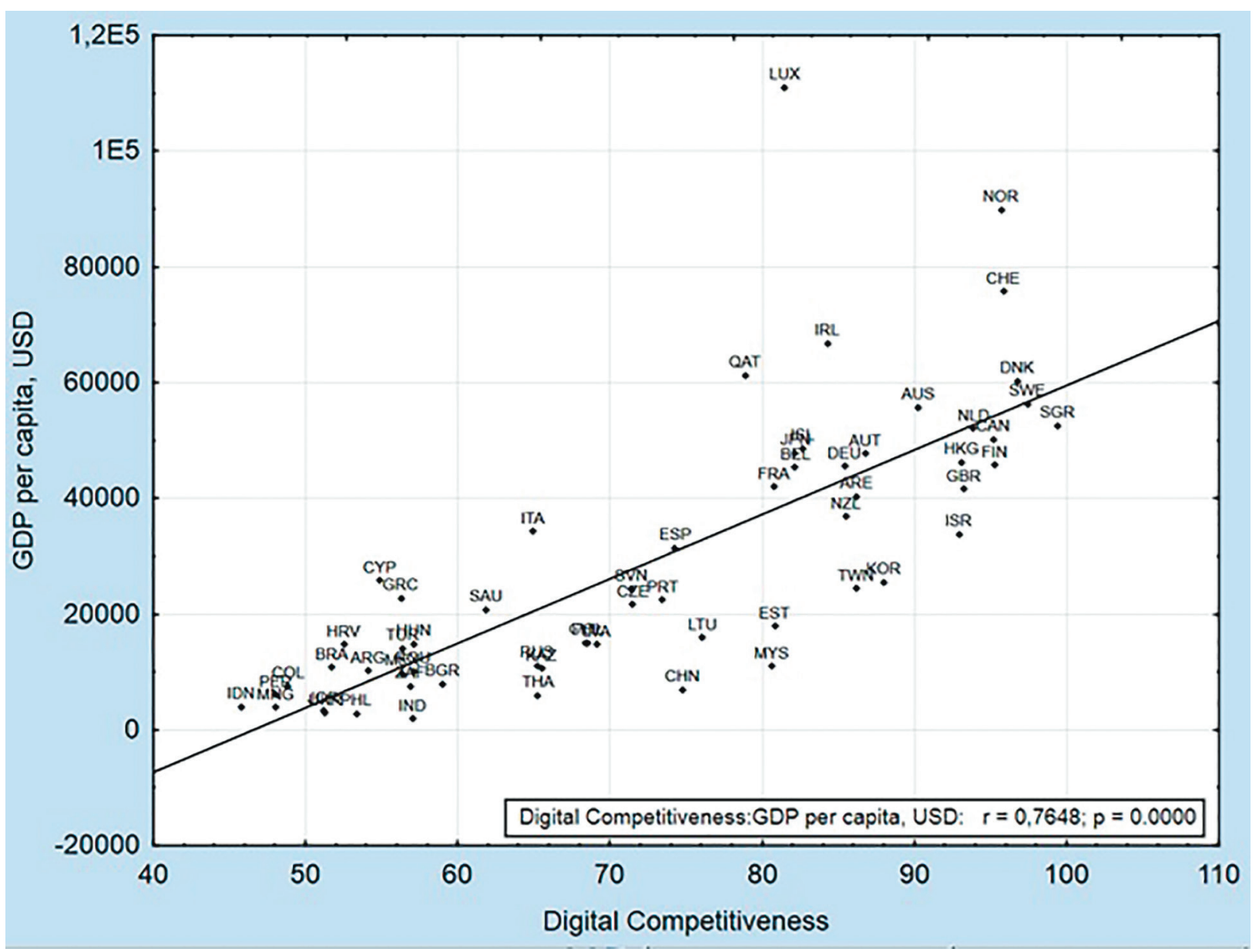

Fig. 7. Digital development and GDP per capita in countries worldwide, 2017

Source: compiled by the authors based on the World Bank (The World Bank database. Retrieved from: https://data.worldbank.org/ (Date of access: 30.07.2020)) and IMD data [32]

According to Russian experts, the low appeal of the Russian FinTech industry is one of the top five barriers for the development of the Russian FinTech market. Other barriers include low purchasing power of the population, shortcomings of government regulation of the FinTech sector, lack of flexibility in the tax system with respect to FinTech, and geopolitical risks (economic sanctions).

Therefore, the experts conclude that most problems faced by Russian FinTech companies result from the current macroeconomic situation.

At the same time, the rating of FinTech strategies in 2018-2019 revealed that the top three strategies aim to implement new technologies, access new markets, and launch new financial products and services.

Apart from that, socially oriented strategies aimed at reducing poverty and increasing GDP are not of key importance for national FinTech companies: they are at the bottom of the ranking.

D. Digital development and economic growth: does the wealth inequality matter?
The final part of this section examines whether digital transformation and financial inclusion affect economic development and contribute to the reduction of income/wealth inequality in countries worldwide.

It is reasonable to expect that digital development in general is strongly positively correlated with economic development, expressed in terms of GDP per capita (Figure 7).

The higher is the level of a country's digital development, including digital technology, knowledge, and the preparedness of an economy to digital transformation, the higher is its GDP per capita $(r=0.76)$.

However, when we introduce into our analysis the inequality indicator, expressed in terms of wealth Gini index ${ }^{1}$, the results are unambiguous (Figure 8).

Figure 8 demonstrates that for economies with moderate wealth inequality (wealth Gini index ranges from 70.5 to 87.2 ), the correlation be-

${ }^{1}$ In general, the wealth Gini coefficients tend to be higher than those for income. 


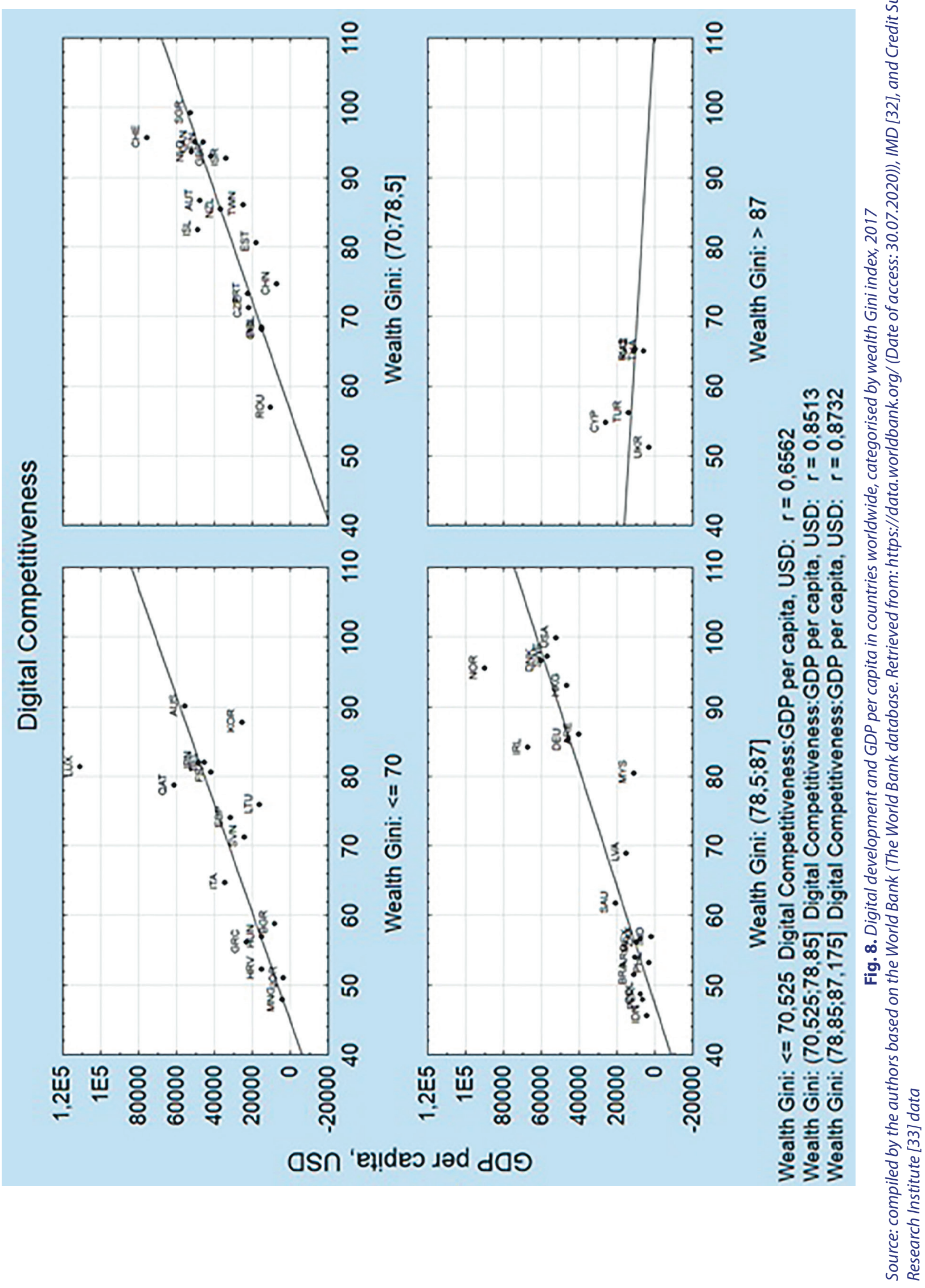




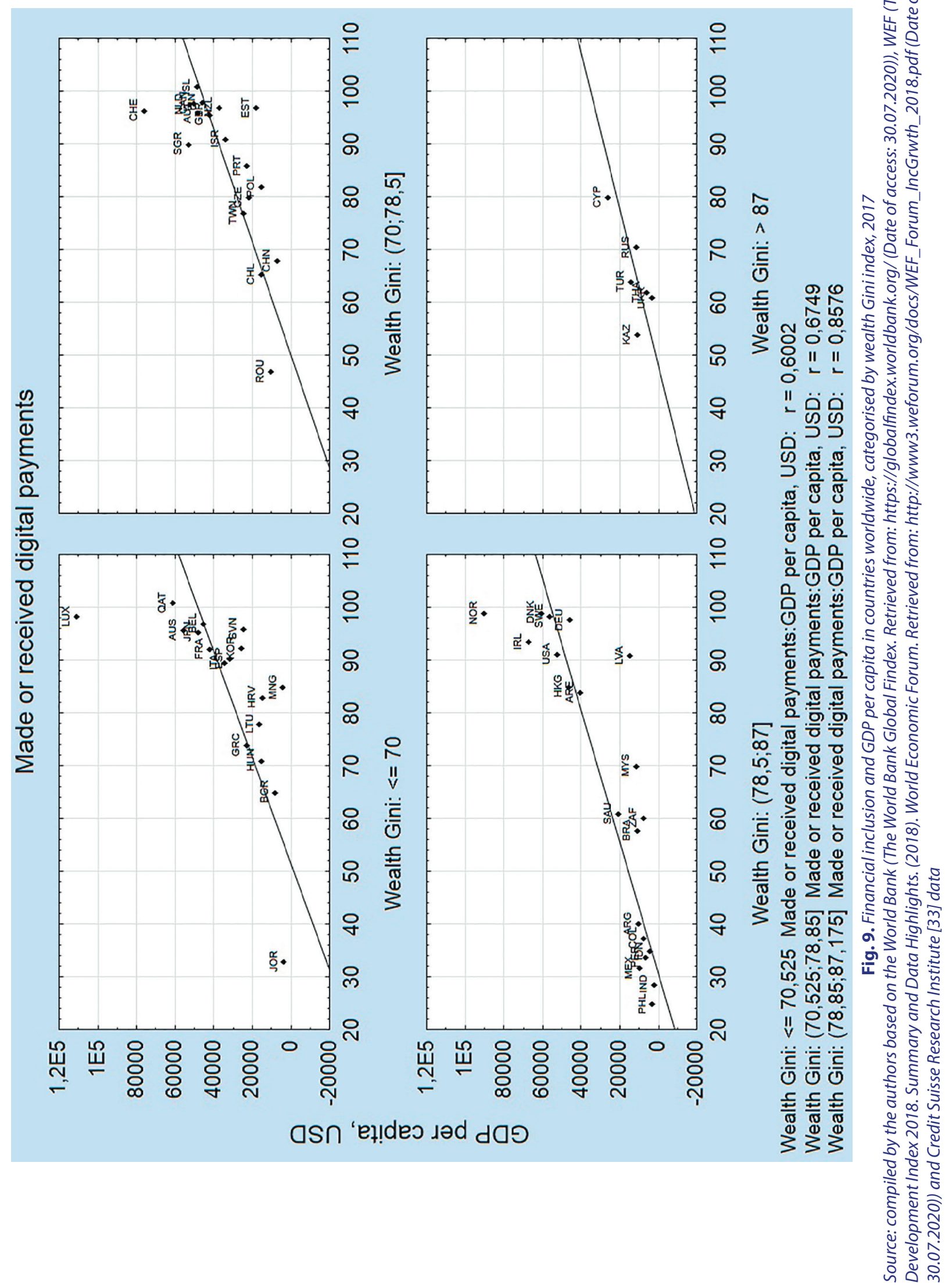


tween digital development and GDP per capita is higher than for those with low wealth inequality (wealth Gini index does not exceed 70.5). In addition, the correlation is stronger for countries with upper-middle wealth inequality, including Russia whose wealth Gini index IS 87.1

The analysis of financial inclusion expressed as the share of adult population making or receiving digital payments in a year and GDP per capita (Figure 9) leads to similar results: the stronger correlation between financial inclusion and GDP per capita is observed for countries with higher wealth Gini index.

To summarise, in most countries with moderate wealth inequality, including Russia, digital transformation can bring more benefits in terms of economic growth than in countries with lower wealth inequality. In such countries, digital transformation can affect wealth inequality in various ways.

First, it can contribute to the decrease in lowskilled and low-paid workforce. Then, increased benefits to owners of robots compared to workers they replace would lead to accelerated replacement of labour by capital. Additionally, wealth inequality through redistribution processes is influenced by tax base erosion. Personal income tax revenue would decrease due to a reduced number of workers, while corporate income tax revenue would decline due to a decrease in tax avoidance and evasion schemes enabled by digital nature of transactions. In turn, these changes would reduce the government's ability to redistribute wealth in order to protect the most vulnerable social groups.

\section{E. Measures to improve digital development in} Russia

The analysis allowed us to conclude that digital measures can be considered a valuable tool for Russia to overcome negative consequences of economic sanctions.

On the first stage of digital transformation, it is necessary to address the following measures.

I) Digital infrastructure

In small towns, digital transformation should be focussed on providing access and developing infrastructure, whereas in larger cities, the resources should be allocated to measures designed to encourage the use of existing infrastructure and access in order to add or create new value.

In addition, to overcome regional digital disparities in Russia, the focus of digital transformation should be shifted from digital technology development, in and of itself, to digital development of human capital. It is essential to improve digital skills training in the medium term, and deepen fi- nancial inclusion for people and businesses in the country in the longer term.

II)Taxation: tax incentives and tax optimisation

Tax incentives promoting digital investment should be designed as strongly targeted, not broadly-based aimed to address a free-rider problem, largely specific for digital economy, and with statutory limited duration allowing to reduce the cost of inefficient projects («sunset» provision).

To address tax avoidance by companies operating in digital sector, it is necessary to alter the Conventions between Russia and other countries for the avoidance of double taxation on income and capital. It is important to start with the definition of substantial digital presence as evidence of permanent establishment in the country (for both Russia and partner-country, when activities are performed solely in a digital environment) to determine nexus rules.

III) Affordability

Better affordability should be a core objective for education to encourage digital skill training for everyone, as well as for fees for digital financial services to deepen financial inclusion that should not worsen wealth inequality in a digital environment and ensure digital responsibility.

\section{Conclusion}

The economic sanctions imposed by the EU and the U.S. against Russia in 2014 negatively affected trade, FDI and the country's overall economic development. The vulnerability to sanctions caused the diversification of trade ties, the Russian "pivot to the East”, as the country shifted from Western partners.

The analysis of external sector data shows that economic sanctions had substantial negative impact on trade and FDI with the main sanctions senders. At the same time, the "pivot to the East" after 2014 has not been implemented yet as much as expected. Both Russian exports and imports to and from China have gradually increased, as contrasted with FDI: the net inward investments from China to Russia have gradually decreased in 20142018. The increase in net inflow in 2019 was due to Chinese investment projects implemented in the Russian Far East, but according to 2020 Q1, net inward investments from China to Russia became negative again.

We considered digital transformation as a way to overcome the negative impact of economic sanctions and promote economic growth coupled with current diversification of trade ties.

To identify whether digital measures can be seen as valuable tools to achieve the desired outcome, we assessed linkages between digital de- 
velopment and wealth inequality. The latter is considered an important macroeconomic indicator, affecting economic growth and financial inclusion.

We discovered that in most countries worldwide with moderate wealth inequality, including Russia, digital transformation could bring more benefits in terms of economic growth, than in countries with lower wealth inequality. This allowed us to address digital policy measures for overcoming negative effects of sanctions in Russia. These measures include digital infrastructure, taxation, and affordability. The obtained results address the problem of optimisation of Russia's behaviour as a target country that is the subject of future research.

\section{References}

1. Maday, M. A. (1913). Economic Sanctions in Cases of Violation of International Law. The Advocate of Peace (18941920), 75(11), 257-259.

2. Lauterpacht, H. (1933). Boycott in international relations. British Yearbook of International Law, XIV, 125-140.

3. Hoffmann, F. (1967). The Functions of Economic Sanctions: a Comparative Analysis. Journal of Peace Research, 4(2), 140-159. DOI: 10.1177/002234336700400204.

4. Doxey, M. (1972). International Sanctions: A Framework for Analysis with Special Reference to the UN and Southern Africa. International Organization. 26(3), 527-550. DOI: 10.1017/S002081830000299X.

5. Barber, J. (1979). Economic Sanctions as a Policy Instrument. International Affairs, 55(3), 367-384. DOI: $10.2307 / 2615145$.

6. MacDonal, R. St. J. (1969). Economic Sanctions in the International System. Canadian Yearbook of International Law, 7, 61-91. DOI: 10.1017/S0069005800011838.

7. Eaton, J. \& Engers, M. (1992). Sanctions. Journal of Political Economy. University of Chicago Press, 100(5), 899-928. DOI: $10.1086 / 261845$.

8. Hufbauer, G., Schott, J. J. \& Elliott, K. A. (1990). Economic Sanctions Reconsidered: History and Current Policy. Institute for International Economics (U.S.): Peterson Institute, 298.

9. Pape, R. A. (1997). Why Economic Sanctions Do Not Work. International Security, 22(2), 90-136. DOI: $10.2307 / 2539368$.

10. Pape, R. A. (1998). Why Economic Sanctions Still Do Not Work. International Security, 23(1), 66-77. DOI: $10.2307 / 2539263$.

11. Tsebelis, G. (1990). Are Sanctions Effective? A Game-Theoretic Analysis. The Journal of Conflict Resolution, 34(1), 3-28. DOI: 10.1177/0022002790034001001.

12. Dashti-Gibson, J., Davis, P. \& Radcliff, B. (1997). On the Determinants of the Success of Economic Sanctions: An Empirical Analysis. American Journal of Political Science, 41(2), 608-618. DOI: 10.2307/2111779.

13. Askari, H. G., Forrer, J., Teegen, H. \& Yang, J. (2003). Economic Sanctions: Examining Their Philosophy and Efficacy. Westport: Greenwood Publishing Group, 223.

14. Hufbauer, G., Schott, J. J., Elliott, K. A. \& Oegg, B. (2007). Economic Sanctions Reconsidered. Washington DC: Peterson Institute, 233

15. Kim, H.-M. (2009). Determinants of the Success of Economic Sanctions: An Empirical Analysis. Journal of International and Area Studies, 16(1), 27-51

16. Escribà-Folch, A. (2010). Economic sanctions and the duration of civil conflicts. Journal of Peace Research, 47(2), 129-141. DOI: 10.1177/0022343309356489.

17. Biersteker, T. J., Eckert, S. E., Tourinho, M. \& Hudáková, Z. (2013). The effectiveness of United Nations targeted sanctions: Findings from the targeted sanctions consortium (TSC). United Nations, 51.

18. Szczepański, M. (Ed.). 2015). Economic impact on the EU of sanctions over Ukraine conflict. Brussels: European Parliamentary Research Service EPRS, 9.

19. Russell, M. (Ed.). (2018). Sanctions over Ukraine. Impact on Russia. Brussels: European Parliamentary Research Service EPRS, 12.

20. Smeets, M. (2018). Can economic sanctions be effective? ERSD-2018-03. World Trade Organization. Economic Research and Statistics Division. Geneva: WTO, 19.

21. Klinova, M. \& Sidorova, E. (2014). Economic Sanctions and EU-Russia Economic Relations. Voprosy Ekonomiki, 12, 67-79. (In Russ.)

22. Minakir, P. A. (2017). «Turn to the East» Policy: Expectations and Reality. Ekonomika regiona [Economy of Region], 13(4), 1016-1029. DOI: 10.17059/2017-4-4 (In Russ.)

23. Nureev, R. M. (Ed.). (2017). Ekonomicheskie sanktsii protiv rossii: ozhidaniya i realnost [Economic Sanctions against Russia: Expectations and Reality]. M.: KNORUS, 194. (In Russ.)

24. Welt, C., Archick, K., Nelson, R. \& Rennack, D. (2019). U.S. Sanctions on Russia. U.S. Congressional Research Service. CRS Report R45415, 69.

25. Pepper, R. \& Garrity, J. (2015). ICTs, Income Inequality, and Ensuring Inclusive Growth. Chapter 1.2. In: The Global Information Technology Report 2015 (pp. 31-38). World Economic Forum. 
26. Graham, M. (Ed.). (2019). Digital Economies at Global Margins. International Development Research Centre: The MIT Press, 390.

27. Demirgüç-Kunt, A., Klapper, L., Singer, D., Ansar, S. \& Hess, J. (2018). The Global Findex Database 2017. Measuring Financial Inclusion and the Fintech Revolution. The World Bank, 151.

28. Gulamhuseinwala, I., Hatch, M. \& Lloyd, J. (2017). FinTech Adoption Index 2017. The rapid emergence of FinTech. EYGM Limited, 44.

29. Hwa, G. (2019). Global FinTech Adoption Index 2019. EYGM Limited, 44.

30. Rudkovskaya. A. (Ed.). (2018). Competing in the Digital Age. Policy Implications for the Russian Federation. Russia Digital Economy Report. International Bank for Reconstruction and Development, The World Bank, 158.

31. Belozyorov, S., Sokolovska, O. \& Kim, Y. (2020) Fintech as a Precondition of Transformations in Global Financial Markets. Forsait [Foresight and STI Governance], 14(2), 23-35. DOI: 10.17323/2500-2597.2020.2.23.35 (In Russ.)

32. Bris, A. \& Cabolis, C. (Eds.). (2018). The IMD World Digital Competitiveness Ranking 2018. IMD World Competitiveness center, 179.

33. Shorrocks, A., Davies, J. \& Lluberas, R. (2018). Global Wealth Databook 2018. Credit Suisse Research Institute, 167.

\section{About the authors}

Sergey A. Belozyorov - Dr. Sci. (Econ.), Professor, Head of the Department of Risk Management and Insurance, Chief Research Associate, Laboratory of Asian Economic Studies, St.-Petersburg State University; Scopus Author ID: 57190407676; https://orcid.org/0000-0001-8711-2192 (7-9, Universitetskaya Emb., Saint Petersburg, 199034, Russian Federation, e-mail: s.belozerov@spbu.ru).

Olena Sokolovska - Cand. Sci. (Econ.), Senior Research Associate, Associate Professor, Department of Risk Management and Insurance, Leading Research Associate, Laboratory of Asian Economic Studies, St.-Petersburg State University, St.-Petersburg State University; Scopus Author ID: 57193993155; https://orcid.org/0000-0002-4259-3786 (7-9, Universitetskaya Emb., Saint Petersburg, 199034, Russian Federation, e-mail: e.sokolovskaya@spbu.ru).

\section{Информация об авторах}

Белозёров Сергей Анатольевич - доктор экономических наук, профессор, заведующий кафедрой управления рисками и страхования, главный научный сотрудник Лаборатории азиатских экономических исследований; СанктПетербургский государственный университет; Scopus Author ID: 57190407676; https://orcid.org/0000-0001-87112192 (Российская Федерация, 199034, г. Санкт-Петербург, Университетская набережная, 7-9; e-mail: s.belozerov@ spbu.ru).

Соколовская Елена - кандидат экономических наук, старший научный сотрудник, доцент кафедры управления рисками и страхования, ведущий научный сотрудник Лаборатории азиатских экономических исследований, Санкт-Петербургский государственный университет; Scopus Author ID: 57193993155; https://orcid.org/00000002-4259-3786 (Российская Федерация, 199034, г. Санкт-Петербург, Университетская набережная, 7-9; е-таil: e.sokolovskaya@spbu.ru).

Дата поступления рукописи: 02.08.2019.

Прошла рецензирование: 23.10.2019.

Принято решение о публикации: 15.09.2020.

Received: 02 Aug 2019.

Reviewed: 23 Oct 2019.

Accepted: 15 Sep 2020. 